Bangladesh J. Plant Taxon. 24(1): 23-32, 2017 (June)

(C) 2017 Bangladesh Association of Plant Taxonomists

\title{
LICHEN DIVERSITY IN AMADIYA AND ROWANDUZ DISRICTS IN IRAQ
}

\author{
Zakaria S. Almola ${ }^{1}$, Basheer A. Al-Ni'ma And Nadeem A. Ramadan \\ Department of Biology, College of Sciences, University of Mosul, Iraq
}

Key words: Lichens; Iraq; physiogeographic regions; Mountain region.

\begin{abstract}
The lichen biota of the Amadiya and Rowanduz districts in the Mountain physiogeographic region in Iraq was sampled in 2013. The samples provided 47 species belonging to 29 genera and 14 families. Among them 37 species are new records for Iraq. All species except Lichinella cribellifera and Thelidium sp. were found in Amadiya district whereas only 13 species occurred in Rowanduz district. Most of the species (59.5\%) were crustose, while $27.6 \%$ were foliose, $12.7 \%$ squamulose and none fruticose. The three most species-rich genera are Caloplaca with 7 species, Collema with 5 species and Aspicilia with 3 species; 6 genera were represented by 2 species and 20 by single species. All saxicolous lichens were calciphilic while the corticolous lichens were acidophilic. The most common and dominant species is Lecanora muralis, found in all 17 studied locations.
\end{abstract}

\section{Introduction}

Iraq is located in the Middle East or South West Asian region above $29^{\circ}$ latitude. Up to date the available knowledge concerning the lichen biota of Iraq is very limited in comparison with those of the neighbour countries, especially Turkey and Iran. In Turkey the study of lichens started in the 19th century by visiting foreign scientists. while in the 1980s Turkish researchers started publishing their contributions. In two decades, between 1980 and 2000, they published more than 200 papers (John, 2007). In Iran the first reports on lichens have been published by Göbel in 1830 and Eversmann in 1831 (Seaward et al., 2004). The preliminary check list of Iranian lichens published in 2004 by Seaward et al. (2004) consists of 396 species of lichenized fungi in addition to 8 species of lichenicolous or allied fungi. For Iraq, however, so far only three publications dealt with the biodiversity of lichens. The first one was published by Steiner (1921). It contains identification results of the lichen specimens that have been collected by Handel Mazzetti during his expedition to Mesopotamia, Kurdistan, Syria and Prinkipo, posthumously published after revision by Alexander Zahlbruckner. The second one was published by Schubert (1973) who collected lichens in Iraq during 1969. The last one was published by Poelt and Sulzer (1974) about Buelliaepigaea in the country. Feuerer (2006) brought the 32 species of these three papers in a single list.

Four physio-geographic regions are distinguished in Iraq viz. Mountain, Upper plains and Foothills, Desert Plateau and Lower Mesopotamian region. Each one is subdivided into a number of districts (Guest, 1966). Our study concerns the Mountain region. This is divided into four districts namely, Amadiya, Rowanduz, Sulaimaniya and Jabel Sinjar. Mountain is considered the richest region by lichen biota due to the suitability of its climate and substrate for lichen growth. Therefore it was selected for the present study that is considered as the first step in preparing a complete check list which will cover all Iraqi physio-geographic regions and districts.

\footnotetext{
${ }^{1}$ Corresponding author. Email: zakaria_sami@yahoo.com

DOI: http://dx.doi.org/10.3329/bjpt.v24i1.33002
} 


\section{Materials and Method}

\section{The study area}

The Mountain region of Iraq extends from West Zakho to southeast of Halabja, and is delimited by the $500 \mathrm{~m}$ contour (the approximate lower limit of the mountain forest). This contour runs irregularly following the margin of the mountain in a general south-easterly direction, very roughly along a line passing near FaishKhabur-Zakho-Simel-Dohuk-Alqosh-Erbil-Kirkuk, then some way north of Tuz and Kifri to Halabja. In the North and Northeast the region is bordered by the Iraqi frontiers with Turkey and Iran, respectively (Guest,1966). According to Guest (1966), the Mountain region contains four physio-geographic districts, two of which are the subject of our study, viz. Amadiya and Rowanduze (Figure 1). Amadiya district is bordered in the east by the Greater Zab tributary, and in the North by the Iraqi frontier with Turkey, while Rowanduz district is located between the Greater and Lesser Zab tributaries of the Tigris River.

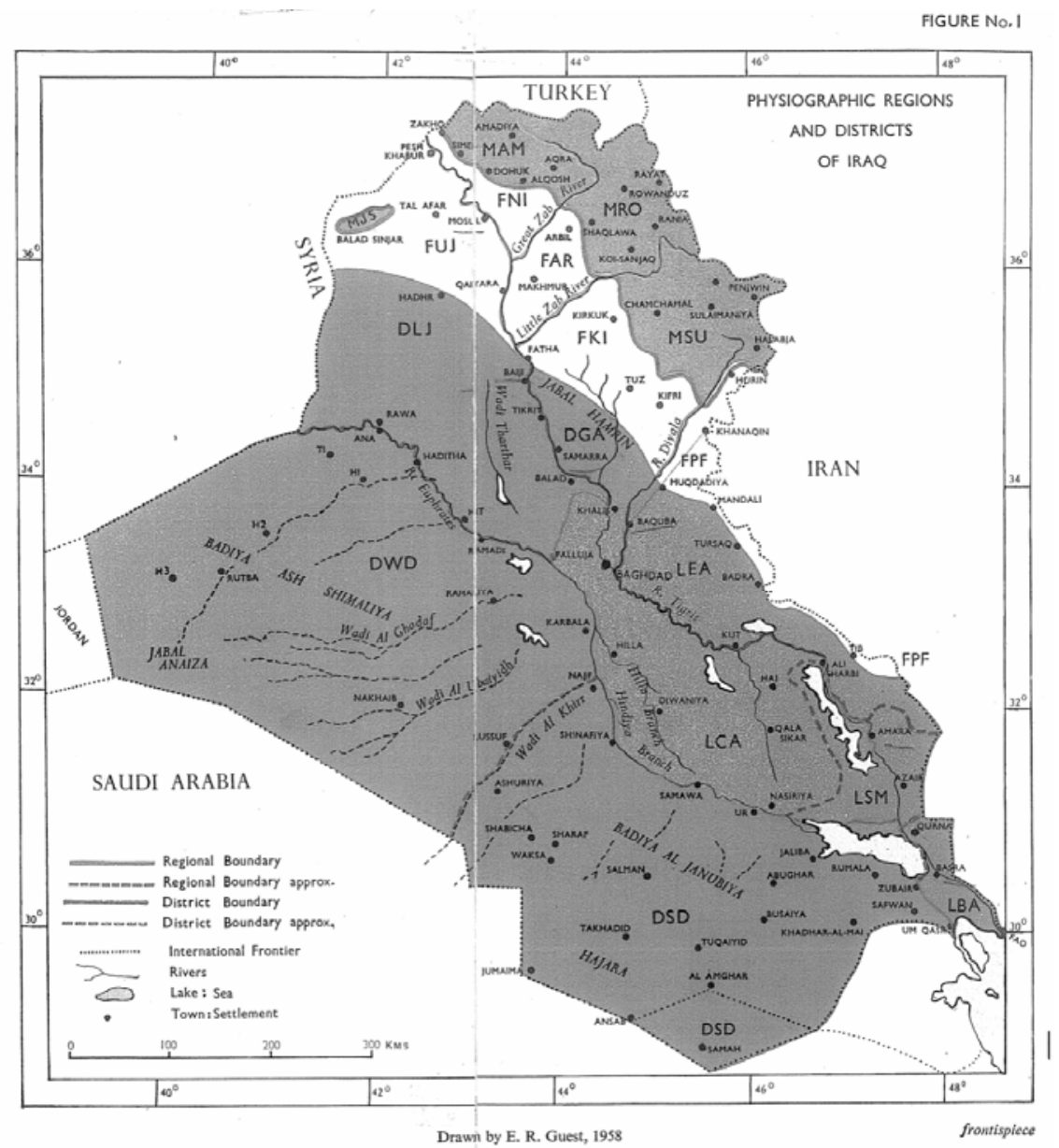

Fig. 1. Physiogeographic regions and districts of Iraq, after Guest (1966). The upper north eastern part represents the mountain region; $\mathrm{MAM}=$ Amadiya district, $\mathrm{MRO}=$ Rowanduz district, $\mathrm{MSU}=$ Sulaimaniya district and MJS= Jabal Sinjar district. 
Geologically, the Iraqi mountains consist mainly of Cretaceous and Eocene limestone and shale, with Paleozoic strata exposed here and there in the cores of eroded anticlines, followed towards the south-west by Miocene Lower Fars gypsum with red shale and thin limestone bands, overlying a basal conglomerate; and ending with Miocene Upper Fars and red shale and the Pliocene Bakhtiari conglomerates.

A belt of confused topography stretching along the north-east frontier from Rowanduz to Halabja is made up of a variety of basic and ultrabasic igneous and metamorphic rocks, with radiolarian chert and a little limestone (Macfadyen, 1966).

The climate of the area is generally warm-temperate. July is the hottest month where air temperature may surpass $40^{\circ} \mathrm{C}$ and January is the coldest month where air temperature approaches zero ${ }^{0} \mathrm{C}$. The rainy period extends, generally, from October to May and the amount of rain is variable during the season and from year to year, for example the minimum and maximum amount of rain that have been fallen on Dohuk city centre between (1980-2005) were 284.3 and 909.7 mm/year during 1994 and 1999, respectively (Al-Rijabo and Bleej, 2010).

Table 1. Average climatological data for two city centers located within the study area.

\begin{tabular}{cccc}
\hline & Unit & Dohuk & Erbil \\
\hline Range of maximum air temp. & ${ }^{0} \mathrm{C}$ & $11.0-42.0$ & $12.4-42.0$ \\
Range of minimum air temp. & ${ }^{0} \mathrm{C}$ & $3.0-27.0$ & $2.4-24.9$ \\
Annual rain fall & $\mathrm{mm} /$ year & 616 & 543 \\
\hline
\end{tabular}

The data represent an average of the last two decades and are obtained from Wikipedia.

\section{Collection, preservation and identification of specimens}

Lichens from different substrates (soil, rocks and tree trunks) have been collected between February and May 2013 from 17 locations, of which 12 located in Amadiya district and 5 in Rowanduz district (Table 2).

Table 2. Names and coordinates of the study locations.

\begin{tabular}{|c|c|c|c|}
\hline \multirow{8}{*}{$\begin{array}{l}\text { Amadiya } \\
\text { District }\end{array}$} & Sl. No. & Locations & Coordinates \\
\hline & 1. & Sharanish & $\begin{array}{l}37^{\circ} 13^{\prime} 52^{\prime \prime} \mathrm{N} \\
42^{\circ} 50^{\prime} 45^{\prime \prime} \mathrm{E}\end{array}$ \\
\hline & 2. & Sarsang & $\begin{array}{l}37^{\circ} 01^{\prime} 04^{\prime \prime} \mathrm{N} \\
43^{\circ} 13^{\prime} 44^{\prime \prime} \mathrm{E}\end{array}$ \\
\hline & 3. & Zawita & $\begin{array}{l}36^{\circ} 51^{\prime} 50^{\prime \prime} \mathrm{N} \\
43^{\circ} 05^{\prime} 34^{\prime \prime} \mathrm{E}\end{array}$ \\
\hline & 4. & By the road, about $2 \mathrm{~km}$ north Gali Balkaif & $\begin{array}{l}36^{\circ} 52^{\prime} 37^{\prime \prime} \mathrm{N} \\
43^{\circ} 20^{\prime} 10^{\prime \prime} \mathrm{E}\end{array}$ \\
\hline & 5. & $\begin{array}{l}\text { By the road about } 1 \mathrm{~km} \text { south east } \\
\text { GaliBalkaif }\end{array}$ & $\begin{array}{l}36^{\circ} 52^{\prime} 22^{\prime \prime} \mathrm{N} \\
43^{\circ} 20^{\prime} 45^{\prime \prime} \mathrm{E}\end{array}$ \\
\hline & 6. & By the road of ShaikhAdi-Zawita & $\begin{array}{l}36^{\circ} 50^{\prime} 01^{\prime \prime} \mathrm{N} \\
43^{\circ} 14^{\prime} 00^{\prime} \mathrm{E}\end{array}$ \\
\hline & 7. & Atrush & $\begin{array}{l}36^{\circ} 49^{\prime} 59^{\prime \prime} \mathrm{N} \\
43^{\circ} 19^{\prime} 38^{\prime \prime} \mathrm{E}\end{array}$ \\
\hline
\end{tabular}


(Contd.).

\begin{tabular}{|c|c|c|c|}
\hline & Sl. No. & Locations & Coordinates \\
\hline & \multirow[t]{2}{*}{8.} & \multirow[t]{2}{*}{ Dinarta } & $36^{\circ} 48^{\prime} 50^{\prime \prime} \mathrm{N}$ \\
\hline & & & $43^{\circ} 59^{\prime} 49^{\prime \prime} \mathrm{E}$ \\
\hline & \multirow[t]{2}{*}{9.} & \multirow[t]{2}{*}{ GaliBalkaif } & $36^{\circ} 48^{\prime} 12^{\prime \prime} \mathrm{N}$ \\
\hline & & & $43^{\circ} 18^{\prime} 07^{\prime \prime} \mathrm{E}$ \\
\hline & \multirow[t]{2}{*}{10.} & \multirow[t]{2}{*}{ ShaikhAdi } & $36^{\circ} 46^{\prime} 30^{\prime \prime} \mathrm{N}$ \\
\hline & & & $43^{\circ} 18^{\prime} 59^{\prime \prime} \mathrm{E}$ \\
\hline & \multirow[t]{2}{*}{11.} & \multirow[t]{2}{*}{ Shaikh Aid road fork } & $36^{\circ} 45^{\prime} 05^{\prime \prime} \mathrm{N}$ \\
\hline & & & $43^{\circ} 19^{\prime} 48^{\prime \prime} \mathrm{E}$ \\
\hline & \multirow[t]{2}{*}{12.} & \multirow[t]{2}{*}{ GaliZanta } & $36^{\circ} 45^{\prime} 03^{\prime \prime} \mathrm{N}$ \\
\hline & & & $43^{\circ} 58^{\prime} 32^{\prime \prime} \mathrm{E}$ \\
\hline \multirow{10}{*}{$\begin{array}{c}\text { Rowanduz } \\
\text { District }\end{array}$} & \multirow[t]{2}{*}{13.} & \multirow[t]{2}{*}{ Gali Ali Beg } & $36^{\circ} 37^{\prime} 55^{\prime \prime} \mathrm{N}$ \\
\hline & & & $44^{\circ} 26^{\prime} 49^{\prime \prime} \mathrm{E}$ \\
\hline & \multirow[t]{2}{*}{14.} & \multirow[t]{2}{*}{ Khalifan } & $36^{\circ} 37^{\prime} 07^{\prime \prime} \mathrm{N}$ \\
\hline & & & $44^{\circ} 25^{\prime} 04^{\prime \prime} \mathrm{E}$ \\
\hline & \multirow[t]{2}{*}{15.} & \multirow[t]{2}{*}{ Heran } & $36^{\circ} 26^{\prime} 07^{\prime \prime} \mathrm{N}$ \\
\hline & & & $44^{\circ} 23^{\prime} 33^{\prime \prime} \mathrm{E}$ \\
\hline & \multirow[t]{2}{*}{16.} & \multirow[t]{2}{*}{ Shaqlawa } & $36^{\circ} 24^{\prime} 30^{\prime \prime} \mathrm{N}$ \\
\hline & & & $44^{\circ} 18^{\prime} 06^{\prime \prime} \mathrm{E}$ \\
\hline & \multirow[t]{2}{*}{17.} & \multirow[t]{2}{*}{ Kori-Kori sheer } & $36^{\circ} 23^{\prime} 02^{\prime \prime} \mathrm{N}$ \\
\hline & & & $44^{\circ} 15^{\prime} 56^{\prime \prime} \mathrm{E}$ \\
\hline
\end{tabular}

In the field, each specimen was preserved in a numbered paper bag and the related essential data were recorded. In the laboratory, the specimens were air dried and preserved permanently in labeled paper bags and deposited in the herbarium of the Biology Department, College of Sciences- Mosul University (MOS).

Using Olympus compound and stereomicroscopes the lichen specimens were identified after the keys following Brodo et al. (2001), Dobson (2011) and Goward et al. (1994).

The identifications were confirmed by Harrie Sipman from the Freie University of Berlin (Germany) on the basis of notes and photos of whole specimens, cross sections and spores.

\section{Results}

List of the taxa with life form, substrate, and distribution in the two districts \# = new record for the district; * = new record for Iraq.

\section{Family: Acarosporaceae \\ Genus: Acarospora}

\#1. Acarospora cervina A. Massal. (1852)

Squamulose; on limestone, in Amadiya district only: locations 1, 2, 9, 11 \& 12.

\section{Genus: Sarcogyne}

*2. Sarcogyne regularis Körb. (1855)

Crustose; on limestone, in Amadiya district only: location 7. 


\section{Family: Candelariaceae \\ Genus: Candelariella}

\#3. Candelariella aurella (Hoffm.) Zahlbr. (1928)

Crustose; on exposed calcareous rocks, in Amadiya district only: locations $1 \& 3$.

*4. Candelariella xanthostigma (Pers. ex Ach.) Lettau (1912)

Crustose; on bark of oak trees, in Amadiya district only: location 2.

\section{Family: Collemataceae \\ Genus: Collema}

*5. Collema cristatum (L.) Weber ex F. H. Wigg. (1780)

Foliose; on hard limestone and soil, in Amadiya district only: locations 1, 5, 7, 10 \& 11.

*6.Collema fuscovirens (With.) J.R. Laundon (1984)

Foliose; on exposed, hard, calcareous rocks and dolomitic limestone, In Amadiya and Rowanduz district: locations $2 \& 16$.

*7. Collema ligerinum (Hy) Harm. (1905)

Foliose; on bark of oak trees, in Amadiya district only: location 5

*8. Collema polycarpon Hoffm. (1796)

Foliose; on exposed, hard, calcareous rocks, in Amadiya district only: location 11.

*9. Collema tenax (Sw.) Ach. (1810)

Foliose; on soil containing calcium, in Amadiya district only: location 9.

\section{Family: Graphidaceae \\ Genus: Diploschistes}

\#10. Diploschistes ocellatus (Fr.) Norman (1853)

Crustose; on calcareous and shale rocks, in Amadiya and Rowanduz districts: locations 4, 5, 6, 10, $12,13 \& 14$

\section{Family: Lecanoraceae \\ Genus: Lecanora}

\#11. Lecanora muralis (Schreber) Rabenh. (1845)

Crustose; on dolomite, limestone, shale and siliceous rocks, in Amadiya and Rowanduz district: all 17 locations.

\section{Family: Lichinaceae \\ Genus: Lichinella}

*12. Lichinella cribellifera (Nyl.) P. P. Moreno \&Egea (1992)

Foliose; on limestone and siliceous rocks, in Rowanduz district only: location 14. 


\section{Family: Megasporaceae \\ Genus: Aspicilia}

\#13. Aspicilia calcarea (L.) Mudd (1861)

Crustose; on limestone, dolomitic limestone and shale rocks, in Amadiya and Rowanduz districts: locations $1,3,5,7,8,11,12,13,14 \& 16$.

*14. Aspicilia contorta (Hoffm.) Kremp. (1861)

Crustose; on limestone and non-calcareous rocks, in Amadiya district only: locations 10, 11 \& 12.

*15. Aspicilia ferruginea (J. Steiner) Szatala

Crustose; on dolomitic limestone, in Amadiya district only: locations 1, 5 \& 9.

\section{Genus: Lobothallia}

*16. Lobothallia praeradiosa (Nyl.) Hafellner (1991)

Crustose; on limestone and siliceous rocks, in Amadiya district only: locations 6, 7 \& 10.

*17. Lobotha lliaradiosa (Hoffm.) Hafellner (1991)

Crustose; on calcareous rocks, in Amadiya district only: location 12.

\section{Genus: Megaspora}

*18. Megaspora verrucosa (Ach.) Hafellner and V. Wirth (1987)

Crustose; on bark of oak trees, in Amadiya district only: locations 2 \& 12.

\section{Family: Parmeliaceae \\ Genus: Melanelia}

*19. Melanelia glabra (Schaer.) Essl. (1987)

Foliose; on bark of oak trees, in Amadiya district only: location 5.

\section{Genus: Parmelina}

*20. Parmelina tiliacea (Hoffm.) Hale (1974)

Foliose; on bark of oak trees, in Amadiya district only: location 6.

\section{Family: Physciaceae \\ Genus: Anaptychia}

*21. Anaptychia desertorum (Rupr.) Poelt (1969)

Foliose; on bark of oak trees, in Amadiya district only: locations 2, 9 \& 10.

\section{Genus: Diplotomma}

*22. Diplotomma hedinii (H. Magn.) P. Clerc\& Cl. Roux (2004)

Crustose; on calcareous rocks, in Amadiya district only: location 1. 


\section{Genus: Phaeophyscia}

*23. Phaeophyscia orbicularis (Neck.) Moberg (1977)

Foliose; on bark of oak and pine trees, in Amadiya district only: locations 2, 10 \& 12.

\section{Genus:Physcia}

*24. Physcia biziana (A. Massal.) Zahlbr. (1901)

Foliose; on bark of oak and hawthorn trees, in Amadiya district only: locations 2, 6, 10 \& 12 .

\section{Genus: Physconia}

*25. Physconia distorta (With.) J. R. Laundon (1984)

Foliose; on bark of oak trees, in Amadiya district only: locations 5, 6 \& 7.

\section{Genus: Rinodina}

\#26. Rinodina bischoffii Hepp (1855)

Crustose; on limestone, in Amadiya and Rowanduz districts: locations 3 \& 17.

\section{Family: Psoraceae \\ Genus: Psora}

\#27. Psora decipiens (Hedwig) Hoffm. (1794)

Squamulose; on calcareous soil, sandy stones and limestone, in Amadiya district only: locations 4, 5, 6, 9, 10 \& 11.

*28. Psora vallesiaca (Schaer.) Timdal (1984)

Squamulose; on calciferous soil, limestone and shale rocks, in Amadiya and Rowanduz districts: locations 1,8 \& 13 .

\section{Family: Ramalinaceae \\ Genus: Lecania}

*29. Lecania koerberianaJ. Lahm (1859)

Crustose; on bark of oak trees, in Amadiya district only: location 2.

\section{Genus: Squamarina}

*30. Squamarina cartilaginea (With.) P. James (1980)

Squamulose; on calcareous rocks and stony calcareous soil, sometimes on mosses that grow on soil, in Amadiya and Rowanduz districts: locations 1, 4, 5, 6, 10, 11, 12 \& 14.

\#31. Squamarina lentigera (Weber) Poelt (1958)

Squamulose; on sandy stones and on calcareous, especially gypsiferous soils, in Amadiya district only: location 9. 


\section{Genus: Toninia}

\#32. Toninia sedifolia (Scop.) Timdal (1991)

Squamulose; on sandy stones and soil, in Amadiya and Rowanduz districts: locations 1, 8, 9 \& 14.

\section{Family: Stereocaulaceae \\ Genus: Lepraria}

*33. Lepraria vouauxii (Hue) R. C. Harris (1987)

Crustoseleprose (powdery), on limestone and siliceous rocks, in Amadiya district only: location 1.

\section{Family: Teloschistaceae \\ Genus: Caloplaca}

*34. Caloplaca aegyptiaca (Müll. Arg.) J. Steiner (1893)

Crustose; on limestone, in Amadiya district only: location 4.

*35. Caloplaca aurantia (Hoffm.) Hafellner (1991)

Crustose; on limestone, In Amadiya and Rowanduz district: locations 4, 5, 10, 11, 12 \& 14.

*36. Caloplaca biatorina (A. Massal.) J. Steiner (1910)

Crustose; on dolomitic limestone, in Amadiya and Rowanduz districts: locations 4, 16 \& 17.

*37. Caloplaca chalybaea (Fr.) Mull. Arg. (1862)

Crustose; on hard calcareous rocks, in Amadiya district only: location 7.

*38. Caloplaca erythrocarpa (Pers.) Zwackh (1862)

Crustose; on calcareous rocks, in Amadiya district only: location 9.

*39. Caloplaca polycarpoides (J. Steiner) M. Steiner \& Poelt (1982)

Crustose; on bark of oak and pine trees, in Amadiya district only: location 2.

*40. Caloplaca variabilis (Pers.) Mull. Arg. (1862)

Crustose; on calcareous rocks, in Amadiya district only: location 1.

\section{Genus:Fulgensia}

*41. Fulgensia schistidii (Anzi) Poelt (1965)

Crustose; on moss Schistidiumapocarpum, in Amadiya district only: location 1.

*42. Fulgensia subbracteata (Nyl.) Poelt (1961)

Crustose; on limestone, dolomitic limestone, shale rocks, sandstones and soil, in Amadiya and Rowanduz district: locations 4, 6, 7, 8, 9, 10, 11, 13, 14 \& 16.

\section{Family: Verrucariaceae \\ Genus: Dermatocarpon}

*43. Dermatocarpon miniatum (L.)W. Mann (1825)

Foliose; on limestone, in Amadiya district only: locations 3 \& 12. 


\section{Genus: Placocarpus}

*44. Placocarpus schaereri (Fr.) Breuss (1985)

Crustose; on limestone, dolomitic limestone and shale rocks, in Amadiya and Rowanduz districts; locations $1,4,5,6,8,13,14,15 \& 16$.

Genus: Thelidium

*45. Thelidium sp. A. Massal. (1855)

Crustose; on limestone, in Rowanduz district only: location 14.

\section{Genus: Verrucaria}

*46. Verrucaria macrostoma Dufour ex DC. (1805)

Crustose; on siliceous rocks, in Amadiya district only: location 4.

\#47. Verrucaria nigrescens Pers. (1795)

Crustose; on dolomitic limestone and shale rocks, in Amadiya and Rowanduz districts: locations $1,6,13,15 \& 17$.

\section{Discussion}

Lichen specimens collected in Amadiya and Rowanduz districts revealed 47 species in 29 genera and 14 families. All these species, except Lichinella cribellifera and Thelidium sp., were found in Amadiya district whereas, 13 species were found in Rowanduz district. Out of 47 species recorded, 37 species are new records for Iraq (marked by an asterisk $\left(^{*}\right)$ in the list) and 10 were known before from the country but are new records for the two districts (marked by "\#"). Of the recorded species $59.5 \%$ were crustose, $27.6 \%$ foliose and $12.7 \%$ squamulose. No fruticose species were found.

Considering the substrates, most species grow only on one type, either soil, rock or trees, with few exceptions such as Aspicilia calcarea, Fulgensia schistidii and Psora decipiens which were collected from a variety of substrates as rock, soil and sandstone. The epiphyte Physcia biziana was found on bark of oak and hawthorn trees.

Like Iraqi higher plants, the epilithic (saxicolous) lichens are lime lovers (calciphiles) since the rocks of the studied area are all calcareous, with available lime, which is normally present as calcium carbonate giving aqueous extracts of higher $\mathrm{pH}$ on the alkaline side of the neutral point (Guest,1966), however the epiphytic species, according to Oran (2011) can be called calcifuges or acidophilic as their results showed that the highest average $\mathrm{pH}$ values of the bark of 18 oak species was 6.16 and the lowest one was 4.76. The epiphytic (corticolous) lichens were found on four species only, viz. Quercus aegilops, Q. infectoria, Crataegus azarolus and Pinus brutia. The largest genera were Caloplaca represented by 7 species, Collema with 5 species and Aspicilia with 3 species. Six genera were represented by two species and 20 by one species only. The distribution of the recorded species was also widely variable, some species as Caloplaca chalybaea, Collema tenax, Sarcogyne regularis and another 18 species were found in one location only, i.e showed narrow distribution. On the other hand, Lecanora muralis was found in all 17 locations, hence it is considered the most dominant species. Comparatively less dominant species are Fulgensia subbracteata and Aspicilia calcarea, both found in 10 locations, then Placocarpus schaereri, which appeared in 9 locations. The most dominant species, Lecanora muralis can be described as an ubiquitous crustose lichen, it grows all over the world including Europe, Asia, North America, 
South Africa, Africa, Macronesia, Oceania and Australasia (Nash et al., 2001). This wide spreading is possibly due to the ability of the species to grow on a wide variety of rocks, basalt, pumice, rhyolite, granite, sandstone and limestone (op. cit.). Moreover it is a desiccation tolerant species and it can overcome dry spells of considerable duration.

\section{Acknowledgements}

The authors are grateful to Dr. Harrie Sipman of Botanical Garden, Berlin of the Freie University, Germany for his helpful collaboration in this work.

\section{References}

Al-Rijabo, W.I. and Bleej, D.A. 2010. Variation of Rainfall with Space and Time in Duhok. Education Science 23(1): 32-43.

Brodo, I.M., Sharnoff, S.D. and Sharnoff, S. 2001. Lichens of North America. New Haven, Yale University Press, London.

Dobson, F.S. 2011. Lichens an Illustrated Guide to the British \& Irish Species. Sixth Revised \& Enlarged Edition. The Richmond Publishing Co. Ltd., England.

Eversmann, E. 1831. In: Lichen emesculentum Pall. et species consimilesadversaria. Nova Acta Acad. Caes. Leopold. Carol. 15(2): 349-362.

Feuerer, T. 2006. Check List of Lichens and Lichenicolous Fungi, Version 1.http://www.checklist.de.

Goward, T., McCune, B. and Meidinger, D. 1994. The Lichens of British Columbia. Ministry of Forests Research Program.

Göbel, F. 1830. Chemische Untersuchungeiner in Persienherabgeregneten Substanz, der Parmelia esculenta .J. Chem. Phys. 60: 393-399.

Guest, E. 1966. Flora of Iraq. Vol. 1, Ministry of Agriculture, Republic of Iraq.

John, V. 2007. Lichenological studies in Turkey and their relevance to environmental interpretation. Bocconea 21: 85-93.

Macfadyen, W.A. 1966. The Geology of Iraq. In: Guest, E. (Ed.). Flora of Iraq. Vol. 1, Ministry of Agriculture, Republic of Iraq.

Nash, T.H., Ryan, B.D., Gries, C. and Bungartz, F. 2001. Lichen Flora of the Greater Sonoran Desert Region. Vol. 2. Arizona state university, Tempe, Arizona, USA.

Oran S. 2011. Investigations on the bark pH and epiphytic lichen diversity of Quercus taxa found in Marmara Region. J. Appl. Biol. Sci. 5(1): 27-33.

Poelt, J. and Sulzer, M. 1974. Die Erdflechte Buelliaepigaea, eine Sammelart. Nova Hedwigia 25(1+2): 173194.

Schubert, R. 1973. Notizenzur Flechtenflora des nördlichen Mesopotamien(Irak). Feddes Rept. 83: 585-589.

Seaward, M.R.D., Sipman, H.J.M., Schultz, M., Maassoumi, A.A., Haji MoniriAnbaran, M. \& Sohrabi, M. 2004. A preliminary Lichen Checklist for Iran. Willdenowia 34: 543-576.

Steiner, J. 1921. Lichenesaus Mesopotamien und Kurdistan sowie Syrien und Prinkipo. Wissenschaftliche Ergebnisse der Expedition nach Mesopotamien 1910. Ann. Naturhist. Staatsmus. Wien 34:1-68. 